\title{
Indonesian Mirabilis jalapa Linn. : A Pharmacognostical and Preliminary Phytochemical Investigations
}

\author{
Endang Hanani*, Rini Prastiwi, Lina Karlina
}

\section{Endang Hanani*, Rini Prastiwi, Lina Karlina}

Faculty of Pharmacy and Sciences, University of Muhammadiyah Prof. Dr. HAMKA J. Delima II/IV Klender, Jakarta 13460, INDONESIA.

\section{Correspondence}

Endang Hanani, Faculty of Pharmacy and Sciences, University of Muhammadiyah Prof. Dr. HAMKA JI. Delima II/IV Klender, Jakarta 13460, INDONESIA.

Phone numbers: +62 21- 8617321/ +62 81-188-1719;

E-mail: hananien@yahoo.com

\section{History}

- Submission Date: 29-05-2017;

- Review completed: 01-06-2017;

- Accepted Date: 03-06-2017

DOI : 10.5530/pj.2017.5.108

Article Available online

http://www.phcogj.com/v9/i5

Copyright

(C) 2017 Phcog.Net. This is an openaccess article distributed under the terms of the Creative Commons Attribution 4.0 International license.

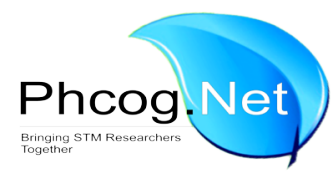

\begin{abstract}
Introduction: Mirabilis jalapa Linn. is an important medicinal plant and used extensively by the people from different countries for the treatment of several disorders. The plant was the raw material for the herb-drug product, so some parameters identified were needed to ensure the safety, quality and efficacy of the product. Objective: The aim of this study was to undertake pharmacognostical studies to fulfill the work required for the identification the $M$. jalapa plant, which is collected from the Bogor area, Indonesia. Methods: Macroscopic and microscopic evaluation, fluorescence standards, phytochemical screening and physicochemical parameters were carried out on the above plant. Results: The parameters values of total ash, water soluble and acid insoluble ash were obtained $11.81,5.06$ and $0.41 \%$, respectively. Moisture content, alcohol, water and ether soluble extractive were found to be $12.41,11.02,18.63$ and $7.17 \%$ respectively. The results of preliminary phytochemical analysis of aqueous ethanolic extract of this drug were positive for alkaloids, tannins, flavonoids, steroid, triterpenoids, saponin, phenols, glycosides and carbohydrate. Thin layer chromatography (TLC) of alcoholic, chloroform and aqueous extracts showed 9, 7 and 4 spots respectively. Conclusion: The present study on botanical pharmacognosy and TLC profile of this plant above thus provides useful information for correct identification and quality control parameters for the crude drugs, and also will be useful in making monograph of the plant. Key words: Chromatography profile, Flourescence character, Microscopic, Nyctaginaceae, Physicochemical.
\end{abstract}

\section{INTRODUCTION}

Mirabilis jalapa Linn.(Nyctaginaceae) is a perennial herb and is has been called by various vernacular names around the world, like Gulambasa' in Ayurveda, 'Gul-abbas' in Hindi, 'Four o' clock' in English, ${ }^{1}$ and "pukul 4" in Indonesia. ' 'Four o' clock' received the name because of habit of opening in the late afternoon. This plant is a widely used traditional medicine in many parts of the world for the treatment of various diseases viz. virus inhibitory activity, ${ }^{3}$ diarrhea, ${ }^{4}$ inflammation treatment, ${ }^{5,6}$ anti-bacterial ${ }^{7,8}$ and anti-spasmodic activity. ${ }^{9}$ The root is believed to be an aphrodisiac as well as diuretic and purgative, and antioxidant activity.,10 Mirabilis jalapa has been extensively used in almost all folklore remedies around the world included Indonesia for treating a variety of conditions. The Indonesia Traditional medicinal ("Jamu") this plant is widely for the treatment of diarrhea, dysentery, muscularpain, and abdominal colics, inflammation, antibacterial, antiviral, and antifungal functions. ${ }^{2}$ To ensure reproducible quality of herbal products, authentication of the starting material is essential. ${ }^{11}$ This present study is concerned to characterization of different pharmacognostical parameters, has included here, botanical identification, microscopic study, powder characteristics, analytical standardization, florescence study and preliminary phytochemical screening. This preliminary study helped for standardization of the crude drug as well as further processing of the sample with some indication regarding the nature of chemical compounds present in it. The pharmaceutical use of traditionally used medicinal plants is hampered due to the lack of standards of quality, safety and efficacy. ${ }^{12}$ The pharmacognostical and preliminary phytochemistry description of a medicinal plant is the first step towards establishing the identity and the degree of purity of such materials and should be carried out before any tests are undertaken. ${ }^{13}$ This study is comprised the Indonesian M. jalapa Linn.

\section{MATERIALS AND METHODS}

\section{Collection and Authentication}

The whole fresh plants material of Mirabilis jalapa Linn. were collected in the month of August September 2016 (from Bogor area, Indonesia), and authenticated by the Research center for Biology, Indonesian Institute of Sciences, Cibinong, Bogor, Indonesia. A voucher specimen has been preserved in the Pharmacognosy laboratory, Faculty of Pharmacy and Sciences, University of Muhammadiyah Prof. Dr. HAMKA, for further references.

\section{Preparation of plant material}

The collected M. jalapa whole plant was washed with tap water. The plant was cut in to small pieces and air-dried thoroughly under shade (at room temperature) for 1 week to avoid direct loss 
of phytoconstituents from sunlight. The shade dried materials were powdered using the pulverizer and sieved up to 60 meshes, and stored in a well closed glass bottle.

\section{Pharmacognostical Evaluation Macroscopic characteristics}

Macroscopical examination was carried out to the freshly plants material, and to the powder. Morphological studies of plants material such as color, size, odor, taste, surface characteristic and fracture were observed based on the description given in Evans $\mathrm{WC}^{14}$ and Indonesian Herb Pharmacopoeia. ${ }^{15}$ Organoleptic characters were observed, noted and photographs were taken in the original environment.

\section{Microscopic characteristics}

Mature, fresh and healthy the different plant parts as leaf, stem, root, etc. and the powder were used for microscopic evaluation.The transverse sections of the different plant parts were prepared by free hand, it was put between the pith and fine sections were cut with the help of a sharp razor. The sections so obtained were cleared using chloral hydrate solution.Preparing for powder microscopy, small amount of whole plant material powder was placed on a glass slide containing one to two drops of chloral hydrate solution. After placing the cover slip, it was warmed gently on spirit lamp to remove air bubbles and then observed under the microscope. Different tissues were observed under the microscope and were photographed. ${ }^{16,17}$

\section{Physicochemical Evaluation}

Physicochemical characteristics such as moisture content, total ash, water soluble and acid insoluble ash tests were performed according to the official methods and the WHO guidelines on the quality control methods for medicinal plant materials. ${ }^{13,1}$ The determination of the extractive values (alcohol, water and ether soluble) of the powdered drug was carried out according to the procedure described in Indonesian Herb Pharmacopoeia, 2008. ${ }^{15}$ Fluorescence characters of powdered and extracts material with different chemical reagents were determined under ordinary and ultraviolet light.

\section{Moisture content}

About $2 \mathrm{~g}$ of the air dried powdered drug was weighed in a watch glass, kept in hot air oven at $105^{\circ} \mathrm{C}$ and dried for a period (about 30 minutes) until constant weight was obtained. Weight loss on drying was noted and difference in weight gives the moisture content of powdered drug. Total moisture content of the drug was noted.

\section{Determination of total ash value}

Two grams of the powdered material was placed in a silica crucible which previously was ignited and tarred crucible accurately weighed.The powdered material was spread as a fine even layer at the bottom of the crucible. The crucible was incinerated until the temperature about $450^{\circ} \mathrm{C}$, and a white material was obtained, that is indicating the absence of carbon. The crucible was cooled and weighed. The procedure was repeated until the constant weights. The percentage of the total ash was calculated with reference to the air dried powdered sample.

\section{Determination of water soluble ash value}

The total ash obtained was boiled with $25 \mathrm{ml}$ of water for five min. The insoluble matter was collected on a ash less filter paper \& and washed with hot water. The insoluble ash was transferred into pre-weighed silica crucible, ignited for $15 \mathrm{~min}$ at a temperature not exceeding $450^{\circ} \mathrm{C}$, cooled and weighed.The procedure was repeated to get the constant weight. The weight of the insoluble matter was subtracted from the weight of total ash. The percentage of water soluble ash was calculated with reference to the air-dried sample drug.

\section{Determination of acid-insoluble ashvalue}

Twenty-five (25) $\mathrm{ml}$ of $2 \mathrm{~N}$ hydrochloric acid was added to the crucible containing the total ash, covered with a watch-glass and boiled gently for 5 minutes. The watch-glass was rinsed with $5 \mathrm{ml}$ of hot water and this liquid added to the crucible. The insoluble matter was collected on an ash less filter-paper and washed with hot water until the filtrate was neutral. The filter-paper containing the insoluble matter was transferred to the original crucible, ignited by gradually increasing the heat to $450^{\circ} \mathrm{C}$ until the constant weight was obtained. The percentage of acid-insoluble ash was calculated with reference to the air dried drugs.

\section{Water extractive value}

Separately place about $10.0 \mathrm{~g}$ (accurately weigh) of whole plant powder of the M. jalapa, in an accurately weighed glass stopper conical flask. Then $100 \mathrm{ml}$ of distilled water was added to the flask and weighed to obtain the total weight including the flask. The contents was macerated, shaken well during the first $6 \mathrm{hrs}$ and allowed to stand for 18 hours. The solution filtered rapidly through a dry filter.Theflask was readjusted to the original total weight with distilled water. Twenty-five $\mathrm{ml}$ of the filtrate was transferred to an accurately weighed, tarred flat-bottomed dish and evaporated to dryness on a water-bath. Finally, it was dried at $105^{\circ} \mathrm{C}$ until the constant weight was obtained. The percentage of the value of water extractive was calculated with reference to the air-dried drug.

\section{Ethanol extractive value}

Same procedure as water extractive valuewas followed using ethanolinstead of distilled water to determine extractable matter in ethanol. The ethanol extractive value was calculated with reference to the air-dried drug.

\section{Ether extractive value}

Same procedure as water extractive valuewas followed using ether to determine extractable matter in ether. The ether extractive value was calculated with reference to the air-dried drug.

\section{Fluorescence Characters}

Fluorescence characters of powdered drug material were sieved through 60 mesh and observations with different chemical reagents. These were observed under visible light, short and long ultraviolet (254 and $366 \mathrm{~nm}$ ). The reagents were methanol, $2 \mathrm{~N}$ hydrochloric acid, 50\% sulphuric acid, $50 \%$ nitric acid and $5 \%$ potassium and sodium hydroxide. ${ }^{18,19}$ The intensity of the coloration determines the abundance of the compound present.

\section{Phytochemical Screening}

Weighed $25 \mathrm{~g}$ of plant material powdered was extracted in a reflux apparatus with $250 \mathrm{ml}$ methanol for 30 minutes. The extracts were filtered and evaporated to dryness under reduced pressure and controlled temperature $\left(40-50^{\circ} \mathrm{C}\right)$. The extracts were subjected to preliminary phytochemical investigation for the detection of following compounds; carbohydrates, protein, steroids and terpenoids,glycosides, flavonoids, alkaloids, tannins, phenolic compounds anthraquinones and saponins, as per the standard procedures described by Indonesian Herb Pharmacopoeia and Harborne. ${ }^{15,20}$ The presence of phyto-constituents from the above plants was presented in the Table 3.

\section{Chromatographic Profile}

The powder material $(10 \mathrm{~g})$ was subjected it to successive Soxhlet extraction with $100 \mathrm{ml}$ solvents: hexane, dichloromethane (DCM) and methanol respectively. The extraction was continued until the solvent became colorless. The 3 extracts were concentrated using a rotary evaporator then analyzed by TLC using silica gel 60 F254 TLC plates for the chromatographic profile.Each extract was faintly dissolved in methanol and 
capillary tubes were used to uniformly apply the dissolved samples on the plates and allowed to dry. The mobile phases for the plates developed were hexane -DCM (6:4), chloroform- methanol (9:1), ethyl acetate methanol (7:3). The plates were dried and observed under visible light and ultraviolet light $366 \mathrm{~nm}$, and by spraying with $10 \%$ sulfuric acid followed by heating at $105^{\circ} \mathrm{C}$ for $5-10$ minutes in an oven. ${ }^{21}$ The retention factor (Rf) value was calculated by using this formula:

$\mathrm{Rf}=$ Distance moved by the solute (compound) / Distanced moved by the solvent front.

\section{RESULTS}

\section{Macroscopic Studies}

Mirabilis jalapa Linn. (Nyctaginaceae) is a perennial herb that reaches a height of 50-100 cm, and a popular ornamental plant grown worldwide for the beauty of its flowers. They have numerous branches and opposite, and the flowers are borne singly or in clusters, and can be red, magenta, pink or yellowish, have light fragrance characteristic taste. Individual flowers are trumpet shaped, about an inch across at the end and
2.5-3.5 cm length. Leaves are green, slightly bitter and having characteristic odor. These are ovate shape, pinnatified, acuminate apex, crenate, cordate base and $5-11 \mathrm{~cm}$ in length, $4-7 \mathrm{~cm}$ in width. The plants have black carrot shaped tubers that can be a foot or more length, and wrinkled black obovoid fruits (Figure 1).

\section{Microscopic Studies}

Transverse section of $M$. jalapa Linn leaf shows presence of multicellular trichomes on both surfaces. The upper and lower epidermis consists of oval shaped parenchyma cells in single layer and also absence of stomata. The vascular bundles are composed of both xylem and phloem in collateral open arrangements. $M$. jalapa Linn. leaf also show the presence of cubuoidal and raphides calcium oxalate crystal (Figure 2A, 3A). Transverse section of $M$. jalapa steam show much trichomes, single cell of epidermis, collenchyma and some layer of parenchyma cells (Figure 2B). Transverse section of the root show the cubuoidal calcium oxalate crystal and raphides calcium oxalate crystal (Figure 2C), and Figure 3A showed also the cubuoidaland raphides calcium oxalate crystal. Fragment of stigma, anther and vascular bundles were showed in Figure 3B, 3C and $3 \mathrm{D}$ respectively.

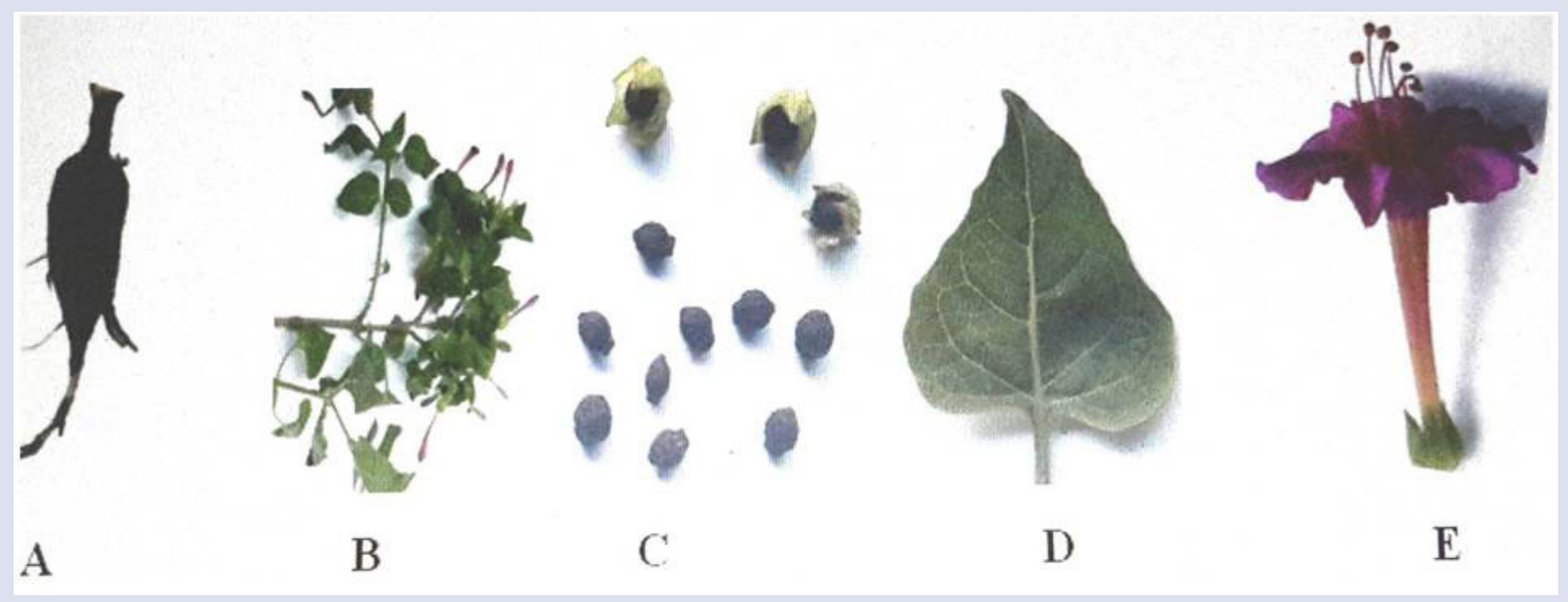

Figure 1: A. Tuber, B. Branch, C. Seeds, D. Fresh leaf, and E. Flower of M. jalapa.
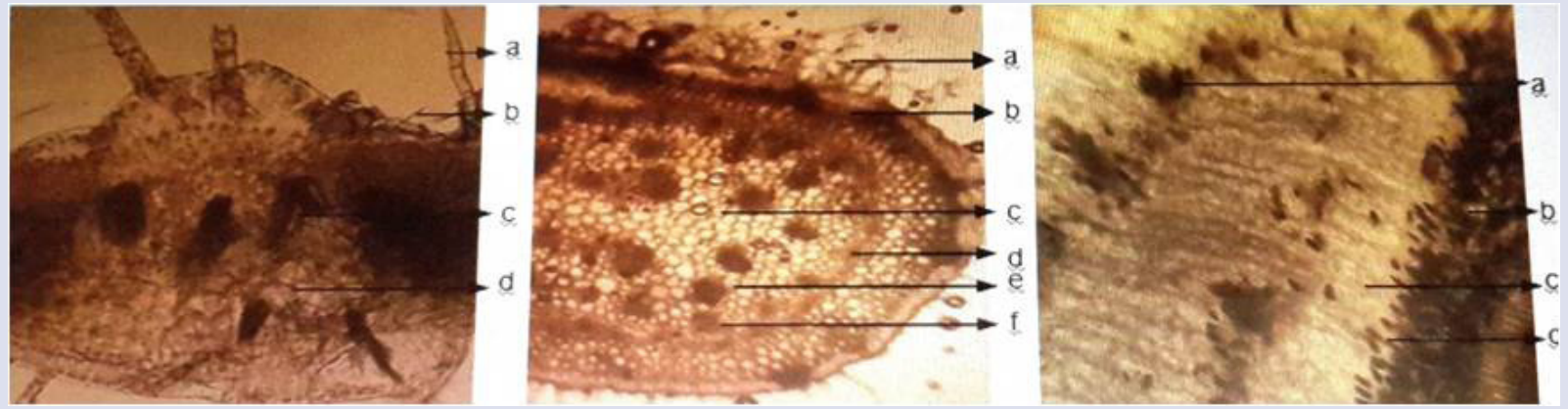

Figure 2: A. Transverse section of leaf: a. trichome; b. raphides calcium oxalate crystal, c. sclereid cell, d. cubuoidal calcium oxalate crystal. B. Transverse section of steam: a. epidermis hair, b. collenchyma, c. pith, d. endodermis, e. phloem, f. xylem, C. Transverse section of root: a. endodermis, b. cubuoidal calcium oxalate crystal, c. cambium, d. raphides calcium oxalate crystal. 

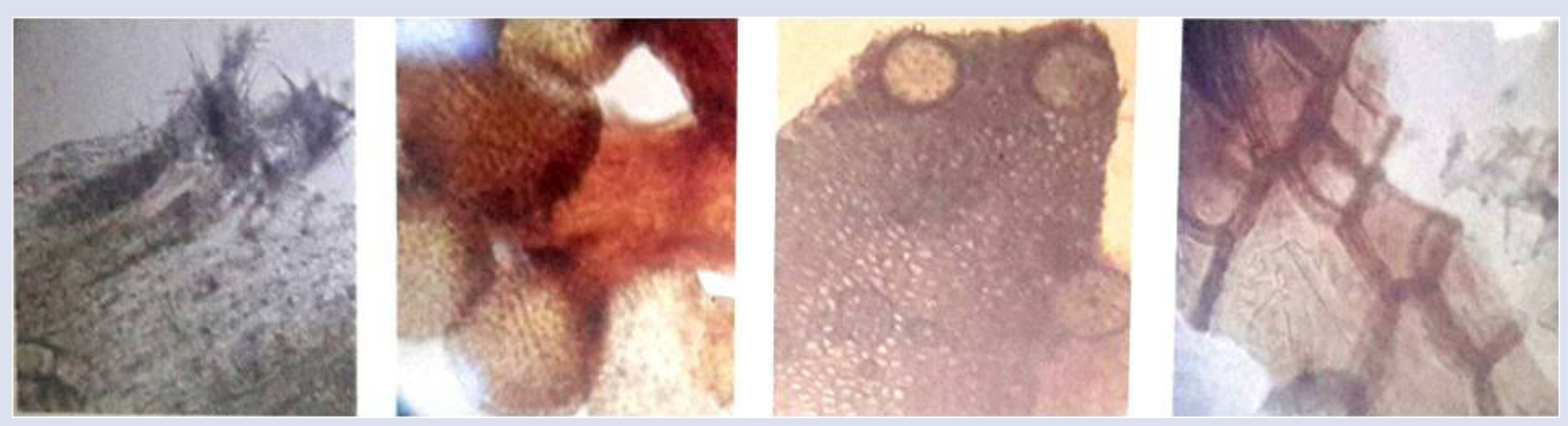

Figure 3: A. Raphides and cubuoidal calcium oxalate crystal, B. Portion of stigma; C. Fragment of anthers with oil gland, D. Vascular bundles

\section{Physicochemical characteristics}

The physico-chemical characteristics such loss on drying, ash values, water, alcohol and ether soluble extractive, were given in the Table 1.

\section{Fluorescence Characters}

Fluorescence characters of powdered material were analyzed under visible and ultraviolet light (254 and $366 \mathrm{~nm}$ ), which signifies their characteristics (Table 2).

\section{Table 1: Physicochemical Parameter of Powder of M. jalapa}

\begin{tabular}{clr}
\hline SI.No & \multicolumn{1}{c}{ Parameters } & Average $(\% \mathrm{w} / \mathrm{w})$ \\
\hline 1 & Moisture content & \\
& Loss on drying & $12.41 \% \pm 0.005$ \\
2 & Ash Value & \\
& a. Total ash & $11.81 \% \pm 0.001$ \\
& b. Water soluble ash & $5.06 \% \pm 0.001$ \\
& c. Acid insoluble ash & $0.41 \% \pm 0.001$ \\
3 & Extractive values & \\
& a. Alcohol soluble & $11.02 \% \pm 0.007$ \\
& b. Water soluble & $18.63 \% \pm 0.007$ \\
& c. Ether soluble & $7.17 \% \pm 0.007$ \\
\hline
\end{tabular}

Table 2: Fluorescence Analysis of Powder and Ethanolic Extract of M.jalapa

\begin{tabular}{llll}
\hline \multicolumn{1}{c}{ Treatment } & \multicolumn{1}{c}{ Normal light } & \multicolumn{1}{c}{ UV $(254 \mathrm{~nm})$} & UV $(366 \mathrm{~nm})$ \\
\hline $\begin{array}{l}\text { Powder } \\
+ \text { Water }\end{array}$ & Green & Light yellow & Light yellow \\
$+\mathrm{KOH}$ & Brown & Dark brown & Brown \\
$+\mathrm{NaOH}$ & Greenish brown & Yellowish brown & Brown \\
$+\mathrm{H} 2 \mathrm{SO} 4$ & Light brown & Bright yellow & Light brown \\
$+\mathrm{HCl}$ & Light brown & Bright yellow & Light yellow \\
$+\mathrm{HNO} 3$ & Yellowish brown & Greenish brown & Greenish brown \\
Alcohol Extract & 70\% & & \\
$+\mathrm{Water}$ & Brown & Yellow & Yellow \\
$+\mathrm{KOH}$ & Yellowish brown & Brown & Light Brown \\
$+\mathrm{NaOH}$ & Greenish brown & Yellowish brown & Greenish brown \\
$+\mathrm{H} 2 \mathrm{SO} 4$ & Light brown & Bright yellow & Yellow \\
$+\mathrm{HCl}$ & Brown & Bright yellow & Yellow \\
$+\mathrm{HNO} 3$ & Light brown & Brown & Light brown \\
\hline
\end{tabular}

\section{Phytochemical Screening}

PreliminaryPhytochemical screening determination of ethanolic extract by some chemical test was carried out. The results were positive for alkaloids, tannins, flavonoids, glycosides, phenols, steroid, triterpenoids and saponin, carbohydrate (Table 3).

\section{Chromatographic Profile}

Thin layer chromatographic profile evaluated of M.jalapa leaves extracts (hexane, DCM, ethanol) constituted different colored phytochemical compounds with different $\mathrm{Rf}$ value. The $\mathrm{Rf}$ values were calculated for the optimum solvent system revealed the presence of promising spots as shown in Table 4.

\section{DISCUSSION}

Macroscopical and microscopical characters will help in the identification of right variety and search for adulterants. The morphological characters of different parts of the plant can serve as diagnostic parameters. Microscopic evaluation is one of the simplest and cheapest methods for establishing the correct identification of the source of the materials. In this microscopical character of $M$. jalapa leaves show the presence of

\section{Table 3: Phytochemical Screening of Plant Extracts of $\boldsymbol{M}$. jalapa}

\begin{tabular}{|c|c|c|}
\hline Phytoconstituens & Test Performed /reagents & Results \\
\hline \multirow[t]{2}{*}{ Carbohydrates } & Fehling & + \\
\hline & Molisch & + \\
\hline \multirow[t]{2}{*}{ Proteins } & Biuret & - \\
\hline & Ninhydrin & - \\
\hline \multirow[t]{3}{*}{ Alkaloids } & Dragendorff & + \\
\hline & Mayer & + \\
\hline & Bouchardat & + \\
\hline Anthraquinones & Borntrager & - \\
\hline \multirow[t]{2}{*}{ Flavonoids } & Shinoda & + \\
\hline & Ammonia & + \\
\hline \multirow[t]{2}{*}{ Glycosides } & Molisch & + \\
\hline & Fehling & + \\
\hline Phenols & Ferric chloride & + \\
\hline Saponins & Foam & + \\
\hline \multirow[t]{2}{*}{ Steroids - terpenoids } & Liebermann & + \\
\hline & BurchardSalkowski & + \\
\hline \multirow[t]{2}{*}{ Tannins } & Gelatin & + \\
\hline & Lead acetate & + \\
\hline
\end{tabular}

Description: $(+)=$ present; $(-)=$ Absent 
Hanani et al: Pharmacognostical investigations of Mirabilis jalapa

Table 4: Chromatographic Profile of Different Extracts of $M$.jalapa Leaves

\begin{tabular}{|c|c|c|c|c|}
\hline Extract & Solvent System & $\begin{array}{l}\text { Total } \\
\text { Spots }\end{array}$ & $\begin{array}{c}\text { Spraying reagent } \\
(10 \% \mathrm{H} 2 \mathrm{SO} 4)\end{array}$ & Rf Value \\
\hline Hexane & Hexane - DCM 6:4. & 9 & $\begin{array}{c}\text { Light brown, light grey, yellow, light grey, light yellow, light grey, light yellow, } \\
\text { light yellow, yellow }\end{array}$ & $\begin{array}{c}0.08,0.17,0.28,0.35,0.50,0.60 \\
0.75,0.86,0.92\end{array}$ \\
\hline DCM & $\begin{array}{l}\text { Choroform - } \\
\text { methanol 9:1. }\end{array}$ & 7 & Light brown, light grey, grey, light yellow, yellow, light blue, light yellow. & $\begin{array}{c}0.05,0.15,0.46,0.60,0.68,0.75 \\
0.90\end{array}$ \\
\hline Ethanol & $\begin{array}{l}\text { Ethyl acetate- } \\
\text { ethanol } 7: 3\end{array}$ & 4 & Light brown, light yellow, yellow, light yellow & $\begin{array}{l}0.05,0.31,0.41 \\
\quad 0.90\end{array}$ \\
\hline
\end{tabular}

cubuoidal $^{22,23}$ and raphides needle in shape of calcium oxalate crystal in Indonesian drug. Drying plays a very important role in the quality as well as purity of the material. Moisture was not so high as to facilitate activation of enzymes and gives suitable condition, to the proliferation of microorganisms, and is an inevitable component of crude drugs, which must be eliminated as far as practicable. The ash values are useful in determining authenticity and purity of drug and also important quantitative standards. Total ash values of drug give an idea of earthy matter or the inorganic composition and other impurities present along with drug. The extractive values are useful for determination of crude drugs and it gives an idea about the nature of the chemical constituents present. Water-soluble indicated the presence of sugar, acids, and inorganic compounds. The alcohol soluble indicated the presence of polar constituents, and ether soluble indicated the presence of non-polar constituents. Physical constants like ash and extractive values help in establishing the pharmacopoeia standards of drug. The physicochemical parameter of this Indonesian drug is almost same with the Indian drug, ${ }^{1,22,23}$ although there were many factors can affected the quality of herbal medicines, such as light exposure, temperature, water availability, nutrients, period and time of collection, method of collecting, drying, packing, storage and transportation of raw material, age and part of the plant collected. Fluorescence study of the drug powder and the extracts helps in the qualitative evaluation which can be used as a reference data for the identification of adulterations. Thin layer chromatographic profile of hexane, DCM and ethanol extracts were carried out with the different mobile phase system to determine how many compoundsin the 3 kinds of these extract, the each compound has a different colored and different Rf value.

\section{CONCLUSION}

The present study on pharmacognosy of different parts of the M.jalapa Linn. provides useful information for quality control parameters for the crude drugs. Macro- and microscopic powder, quantitative and fluorescence standards discussed here can be considered as identifying parameters to substantiate and authenticate the drug. This preliminary information is necessary for standardization of the plant material used in the formulation of drugs. The results of the present investigation are significant and encouraging towards the goal for future utilization and standardization of above plants. M.jalapao rigin from Indonesia, India and South India showed the same phytoconstituens compounds such as alkaloids, tannins, flavonoids, terpenoids, glycosides, saponins and carbohydrates.

\section{ACKNOWLEDGEMENT}

The authors are very much thank full to Mr. Budi AsmanM.Ph., Dean of Faculty of Pharmacy and Sciences, University of Muhammadiyah Prof. Dr. HAMKA, Klender, Jakarta, Indonesia for providing laboratory facilities for the present research work.

\section{CONFLICT OF INTEREST}

Authors declare no conflict of interest.

\section{REFERENCES}

1. Aher AN, Kavita B, Sunanda M, Shubhangi B. Pharmacognostic, phytochemical and pharmacological investigation on leaf and root of Mirabilis jalapa Linn. (Nyctaginaceae). Int J Pharm Sci Rev Res. 2016;40(2):132-6.

2. Eisai, Medicinal Herbs Index in Indonesia, PT Eisai Indonesia, 1986.

3. Vivanco JM. Antiviral and antiviroid activity of MAP containing extracts from Mirabilis jalapa roots. Phytopathological Society. 1999;83(12):1116-21.

4. Sumithra P, Varalakshmi S, Devasena K. Phytochemical analysis and antibacterial activity of Mirabilis jalapa flower against gastro intestinal pathogens. Intern $\mathrm{J}$ of Science and Research (IJSR). 2014;3(12):1167- 70

5. Nath, LR, Manjunath KP, Savadi RV, Akki KS. Anti-inflammatory activity of Mirabilis jalapa Linn. J of Basic and Clinic Pharmacy. 2010;1(2):93-6.

6. Singh M, Kumar V, Singh I, Gauttam V, Kalia AN. Anti-inflammatory activity of aqueous extract of Mirabilis jalapa Linn. leaves. Pharmacognosy Research. 2010;2(6):364-7. doi: 10.4103/0974-8490.75456.

7. Kusamba C, Byaman K, Mbuyi WM. Anti-bacterial activity of Mirabilis jalapa seed powder. J Ethnopharmacol. 1991;35(2):197-9.

8. Maneemegalai S, Naveen T. Evaluation of antibacterial activity of flower extracts of Mirabilis jalapa L. Ethnobotanical Leaflets. 2010;14:182-92.

9. Aoki A, Cortes AR, Ramifrez MC, Hernandez MG, Lopez-Munoz FJ. Pharmacological study of anti-spasmodic activity of Mirabilis jalapa Linn. flowers. JEthnopharmacol. 2008;116(1):96-101.

10. Selvakumar P, Kaniakumari D, Loganathan V. Phytochemical screening and antioxidant activity of red flowered Mirabilis jalapa leaf in different solvents. International J of Pharma and Bio Science. 2012;3(4):440-6.

11. Chandra S. Importance of pharmacognostic study of medicinal plants: An overview. J of Pharmacognosy and Phytochemistry. 2014;2(5):69-73.

12. Kamboj VP. Herbal Medicine. Current Science. 2000;78(1):35-9.

13. World Health Organization. Quality control methods for medicinal plant materials. WHO Library, Geneva. 1998;1-115.

14. Evans WC. Trease and Evans Pharmacognosy, 15 $5^{\text {th }}$ edition, WB Saunders, Edinburgh London, New York, Philadelphia, St Louis, Sydney Toronto, 2000

15. Anonymous. Farmakope Herbal Indonesia. Ed I., Departemen Kesehatan Republik Indonesia (Department of Health of RI) Jakarta, Indonesia. 2008;169-78.

16. Muhammad N, Saeed M, Barkatullah, Ibrar M, Khan H. Pharmacognostic studies of Viola betonicifolia. Afr J Pharm Pharmacol. 2012;6(1):43-7.

17. Hanani E, Ladeska V, Astuti AC. Pharmacognostical and phytochemical evaluation of Indonesian Peperomia pellucida (Piperaceae). International J of Biological and Pharmaceutical Research. 2017;8(1):10-7.

18. Kokashi CJ, Kokashi RJ, Sharma M. Fluorescence of powdered vegetable drugs in ultra-violet radiation. J American Pharm Assoc. 1958;47:715- 7.

19. Shailendra S, Anil B. Pharmacognostical and phytochemical analysis of stem part of the traditional herb : Zaleya Govindia. Asian J of Pharmaceutical and Clinical Research. 2014;7(2):32-5.

20. Harborne, JB. A Guide to Modern Techniques of Plant Analysis. Phytochemical Methods. Chapman and Hall London. 1998:60-6.

21. Wagner H, Bladt S, Zgainski EM. Plant Drug Analysis, A Thin Layer Chromatography Atlas. Springer-Verlag Berlin Germany. 1984;1-17.

22. Lekshmi RN, Manjunath KP, Savadi RV, Akki KS. Pharmacognostical and phytochemical studies of Mirabilis jalapa Linn. leaves. Pharmacogn J. 2009;1(2):111-5

23. Devi SL, Sunny M, Janaipriya N, Nagatami S, Babu TS, Vinupriya S. Pharmacognostical and phytochemical studies of Mirabilis jalapa Linn. South Asia J of Biology and Science. 2011;1(1):1-6 
GRAPHICAL ABSTRACT

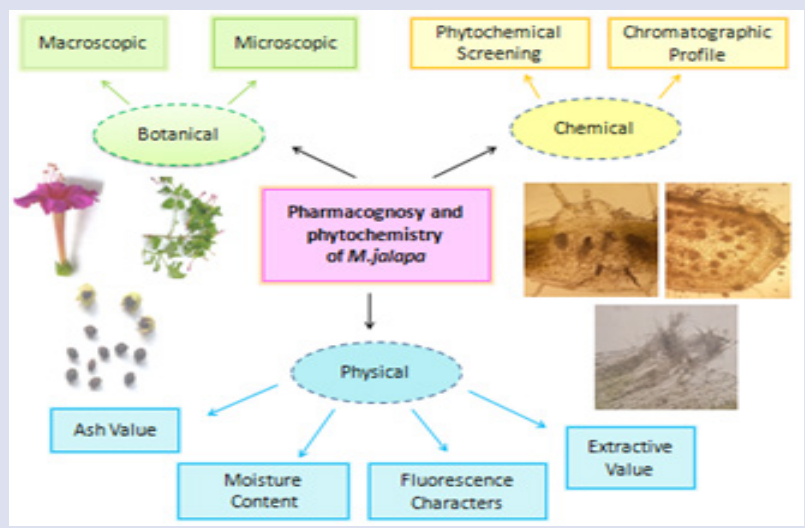

\section{HIGHLIGHTS OF PAPER}

- Mirabilis jalapa Linn. has been called by various vernacular names around the world, like Gulambasa' in Ayurveda, 'Gul-abbas' in Hindi, 'Four o' clock' in English, 1 and "pukul 4" in Indonesia.

- This plant is used for treatment of various diseases viz. virus inhibitory activity, diarrhea, inflammation treatment, anti-bacterial and anti-spasmodic activity.

- M.jalapa origin from Indonesia, India and South India showed the same phytocons-tituens compounds.

- This is the first report of Indonesian M. jalapa Linn. on the pharmacognostical studies, and provides useful information for quality control parameters for the crude drugs.

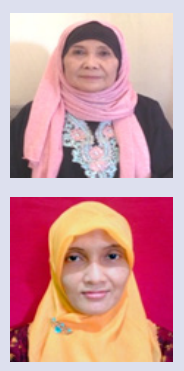

\section{AUTHOR PROFILE}

Endang Hanani: Lecturer and researcher at Faculty of Pharmacy and Sciences, University of Muhammadiyah Prof. Dr. HAMKA, Klender, Jakarta 13460, Indonesia. Also as Professor Pharmacognosy and Phytochemistry.

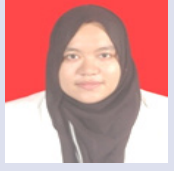

Lina Karlina: Graduate student at Faculty of Pharmacy and Sciences, University of Muhammadiyah Prof. Dr. HAMKA, Klender, Jakarta 13460, Indonesia.

Cite this article : Hanani E, Prastiwi R, Karlina L. Indonesian Mirabilis jalapa Linn. A Pharmacognostical And Preliminary Phytochemical Investigations. Pharmacog J. 2017;9(5):683-8. 